Edubiotik : Jurnal Pendidikan, Biologi dan Terapan
ISSN 2528-679X (print), ISSN 2597-9833 (online)
Volume 5, Nomor 01, Tahun 2020, Hal. 18-28
Available online at:
http:/lejurnal.budiutomomalang.ac.id/index.php/edubiotik

\title{
Research Article \\ Pengembangan multimedia interaktif biologi berbasis website dalam menghadapi revolusi industri 4.0
}

\author{
Ali Sadikin, Asni Johari, Lili Suryani
}

Program Studi Pendidikan Biologi, Universitas Jambi, Jambi, Indonesia

Email: alisadikin@unja.ac.id*, johariasni13@gmail.com, suryani.lili47@gmail.com

\begin{tabular}{|c|c|}
\hline Informasi Artikel & ABSTRACT \\
\hline $\begin{array}{l}\text { Submit: } 04-01-2019 \\
\text { Diterima: } 25-02-2020 \\
\text { Dipublikasikan: } 27-02-2020\end{array}$ & $\begin{array}{l}\text { Web-based interactive biology multimedia to support the learning of the revolution } 4.0 \\
\text { era is not yet available to the fullest. The purpose of this research is to develop } \\
\text { interactive biology-based website multimedia in the face of the industrial revolution } 4.0 \text {. } \\
\text { The research method used, namely research \& development with ADDIE product } \\
\text { development models that include the analysis, design, development, implementation, } \\
\text { and evaluation stages. The research instruments used were interview transcripts, } \\
\text { observation sheets, material and media expert questionnaires, and product trial } \\
\text { questionnaires for } 46 \text { students. Qualitative data in the form of expert validator } \\
\text { suggestions and comments were analyzed descriptively. Quantitative data is processed } \\
\text { into interval data using a Likert scale. The results showed that website-based interactive } \\
\text { multimedia biology was declared valid in the media aspect (90\%, very good criteria), } \\
\text { material aspects (87.5\%, very good criteria), and attractiveness aspects (88\%, very } \\
\text { good criteria). The conclusion of this research, which is interactive multimedia based } \\
\text { on website biology, is suitable for biology learning. } \\
\text { Key words: Industrial revolution 4.0, Multimedia, Website }\end{array}$ \\
\hline Penerbit & ABSTRAK \\
\hline $\begin{array}{l}\text { Program Studi Pendidikan Biologi, } \\
\text { IKIP Budi Utomo, Malang, Indonesia }\end{array}$ & $\begin{array}{l}\text { Multimedia interaktif biologi berbasis website untuk mendukung pembelajaran era } \\
\text { revolusi } 4.0 \text { belum tersedia secara maksimal. Tujuan penelitian ini adalah untuk } \\
\text { mengembangkan multimedia interaktif biologi berbasis website dalam menghadapi } \\
\text { revolusi industri } 4.0 \text {. Metode penelitian yang digunakan, yaitu research \& development } \\
\text { dengan model pengembangan produk ADDIE yang meliputi tahap analisis, desain, } \\
\text { pengembangan, implementasi, dan evaluasi. Instrumen penelitian yang digunakan, } \\
\text { yaitu transkrips wawancara, lembar observasi, angket ahli materi dan media, dan } \\
\text { angket uji coba produk kepada } 46 \text { siswa. Data kualitatif berupa saran dan komentar }\end{array}$ \\
\hline 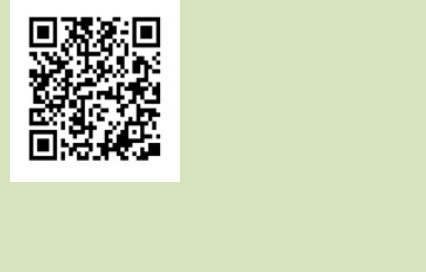 & $\begin{array}{l}\text { validator ahli dianalisis secara deskriptif. Data kuantitatif diolah menjadi data interval } \\
\text { menggunakan skala likert. Hasil penelitian menunjukkan bahwa multimedia interaktif } \\
\text { biologi berbasis website dinyatakan valid pada aspek media ( } 90 \% \text {, kriteria sangat baik), } \\
\text { aspek materi ( } 87,5 \% \text {, kriteria sangat baik), dan aspek kemenarikan ( } 88 \% \text {, kriteria } \\
\text { sangat baik). Simpulan penelitian ini, yaitu multimedia interaktif biologi berbasis website } \\
\text { layak digunakan untuk pembelajaran biologi. } \\
\text { Kata kunci: Multimedia, Revolusi industri } 4.0 \text {, Website }\end{array}$ \\
\hline
\end{tabular}

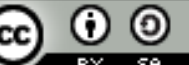

This Edubiotik: Jurnal Pendidikan, Biologi dan Terapan is licensed under a CC BY-SA (Creative Commons Attribution-ShareAlike 4.0 International License)

\section{PENDAHULUAN}

Di era revolusi industri 4.0 internet sangat mempengaruhi berbagai aspek baik ekonomi, kesehatan, kebudayaan maupun pendidikan (Muhaimin et al., 2019). Internet dan teknologi informasi bagi 
guru dan siswa memudahkan mereka dalam melaksanakan pembelajaran. Tidak dibatasi lagi oleh ruang dan waktu, mereka dapat menyelenggarakan pembelajaran secara online (Prasojo et al., 2018). Pengaruh internet dapat menjadi potensi besar dalam mengembangkan pembelajaran dengan sistem online yang dapat memungkinkan peserta didik dapat mengakses informasi secara fleksibel tanpa batas waktu dan temapt (Prawiradilaga, 2016). Internet mampu menstimulasi guru untuk menciptakan media pembelajaran berbasis website yang dapat diakses oleh siswa dimana dan kapan saja (Muhaimin et al., 2019). Guru harus menjamin akan kebutuhan belajar siswa. Guru tidak bisa lagi mengajar seperti biasa masuk kelas membawa buku lama, dengan metode lama dan jumlah sumber belajar yang terbatas. Diperlukan pengembangan multimedia berbasis website untuk memenuhi kebutuhan siswa dalam proses pembelajaran biologi (Sadikin \& Hakim, 2019).

Teknologi berpengaruh terhadap sistem pembelajaran di sekolah (Prasojo, Habibi, \& Mukminin, 2017). Permasalahan yang dijumpai di sekolah terhadap media yang digunakan guru meliputi buku cetak, LKS, papan tulis dan penggunaan PowerPoint (Mukminin, Habibi, Muhaimin, Haryanto, \& Setiono, 2019). Guru belum menerapkan media berbasis website dalam kegiatan belajar-mengajar. Masalah yang berkaitan dengan terbatasnya sumber media tentunya tidak sejalan dengan perkembangan teknologi yang sangat canggih dan semakin modern (Prasojo et al., 2018). Layanan internet seharusnya memudahkan siswa dalam mengakses sumber belajar. Kemajuan teknologi bukan menjadi alasan bagi siswa untuk tidak belajar. Apabila materi pembelajaran diintegrasikan dalam bentuk website maka siswa bisa mengaksesnya karena tidak terikat ruang dan waktu. Siswa bisa kapan saja dan dimana saja belajar dengan mandiri, sehingga dengan teknologi yang canggih yang ada sekarang, bisa dimanfaatkan dalam hal-hal yang positif (Murdiyani, 2012). Oleh karena itu, materi pembelajaran telah disusun sedemikian rupa untuk mempermudahkan siswa dalam belajar, siswa tidak terlalu banyak membawa beban buku ke dalam kelas karena pembelajaran berbasis website dalam sistem pengajaran saat ini telah memberikan solusi terhadap permasalahan umum yang berkaitan dengan proses pembelajaran di sekolah (Januarisman \& Ghufron, 2016).

Kelemahan-kelemahan pada metode pembelajaran yang diterapkan dengan menggunakan buku menyebabkan beberapa dari siswa tidak fokus pada materi yang sedang diajarkan karena minimnya interaksi siswa terhadap materi (Putu, I Ketut, \& I Nyoman Gede, 2014). Media buku mampu merubah sikap siswa, tetapi dengan media elektronik sikap siswa dapat berubah menjadi aktif dikarenakan dengan media elektronik memungkinkan siswa untuk langsung berinteraksi dan menyerap pesan dari media tersebut (Putu et al., 2014). Karena itulah, guru membutuhkan media alternatif lain sebagai bahan ajar untuk memberikan ilustrasi dan pemahaman yang lebih dengan menggunakan aplikasi berupa media pembelajaran berbasis multimedia. Multimedia dapat berpengaruh secara signifikan terhadap motivasi dan hasil belajar siswa (Anggraeni, Sulton, \& Sulthoni, 2019; Istigfar, Wijaya, \& Nurmila, 2018; Kurniawan \& Masjudin, 2017).

Media animasi merupakan salah satu bagian dari multimedia yang melibatkan panca indera manusia (Ferry \& Kamil, 2019). Animasi sering digunakan pada dunia perfilman, buku komik dan majalah anak-anak (Faryanti \& Panjaitan, 2016). Seiring dengan perubahan teknologi yang semakin pesat, media animasi telah memasuki dunia pendidikan sebagai salah satu sarana edukasi yang mampu menimbulkan motivasi siswa dalam belajar (Sukiyasa \& Sukoco, 2013). Animasi dapat meningkatkan hasil belajar siswa (Ferry \& Kamil, 2019). Hal ini sesuai dengan perubahan teknologi komputer yang telah mengalami kemajuan yang pesat sehingga memberikan kemudahan bagi guru untuk menyiapkan media pembelajaran. Animasi dapat meningkatkan hasil belajar aspek kognitif siswa (Riyanto \& Susilawati, 2019). Media animasi yang diterapkan dalam pembelajaran mampu meningkatkan respon positif siswa 
(Faryanti \& Panjaitan, 2016). Multimedia interaktif yang dimanfaatkan dalam pembelajaran mampu mempengaruhi hasil belajar siswa dibandingkan dengan buku teks (Wilsa, 2019).

Pemanfaatan animasi yang terintegrasi dengan website dalam pembelajaran akan menimbulkan perubahan pengetahuan dan pemahaman dari siswa. Mengingat website adalah sebuah kumpulan dari halaman web yang saling berhubungan dan dapat diakses melalui halaman depan (home page) menggunakan sebuah browser juga jaringan internet (Aprilia, Wijaya, \& Suryadi, 2014). Perubahan tersebut tentunya mengarahkan siswa lebih memahami materi pembelajaran. Siswa akan konsentrasi dalam belajar yang berkaitan dengan makna visual yang di tampilkan oleh media animasi (Ferry \& Kamil, 2019). Tampilan visual media animasi memperlancar pencapaian tujuan (Sadikin \& Hakim, 2019; Arsyad, 2013). Setiap siswa yang melihat ataupun yang mendengar penyajian media menerima pesan yang sama (Suprihatin, 2017). Meskipun para guru menafsirkan isi pelajaran dengan cara yang berbeda-beda, dengan penggunaan media animasi hasil tafsiran itu dapat dikurangi sehingga informasi yang sama dapat disampaikan kepada siswa sebagai landasan untuk pengkajian, latihan, dan aplikasi lebih lanjut.

Berdasarkan hasil observasi yang telah dilakukan peneliti di SMA Negeri 4 Kota Jambi, didapatkan bahwa di sekolah tersebut sudah memanfaatkan teknologi informasi sebagai penunjang proses pembelajaran. Dimana sekolah tersebut telah memiliki proyektor di setiap kelas yang dipergunakan untuk menampilkan slide presentasi bahan ajar ataupun diskusi dalam proses belajar dan ada laboratorium komputer serta laboratorium biologi yang mendukung proses pembelajaran. Sebagian besar siswa telah memiliki gadget, misalnya smartphone atau laptop serta WiFi (Wireless Fidelity) di sekolah. Pada penelitian ini produk media pembelajaran yang dikembangkan adalah multimedia interaktif yang diintegrasikan dengan website. Multimedia interaktif berbasis website ini membuat materi pelajaran biologi tepatnya materi sistem pernapasan manusia lebih mudah dipahami oleh siswa karena dilengkapi dengan materi, gambar, dan animasi serta dapat diakses dimana saja dan kapan saja tidak terikat oleh ruang dan waktu. Berdasarkan uraian di atas, tujuan penelitian ini yaitu mengembangkan multimedia interaktif biologi berbasis website dalam menghadapi revolusi industri 4.0.

\section{METODE PENELITIAN}

Metode penelitian yang digunakan, yaitu jenis penelitian pengembangan (research and development methode). Model pengembangan produk yang digunakan dalam pengembangan ini adalah model ADDIE. Adapun tahapan model pengembangan ADDIE meliputi analisis/analyze, desain/design, pengembangan/development, impementasi/impelement, dan evaluasi/evaluation (Seel, Lehmann, Blumschein, \& Podolskiy, 2017). Model pengembangan ADDIE dapat dilihat pada Gambar 1.

Tahap analisis dilakukan di SMA N 4 Kota Jambi yang melibatkan 40 orang siswa, dan 3 orang guru untuk melakukan analisis kebutuhan. Analisis meliputi kebutuhan siswa, karakteristik siswa, media dan materi pelajaran biologi yang diaggap sulit untuk dipahami oleh siswa. Pada tahap desain (design) yang dilakukan adalah menyusun rancangan tampilan media dan mengumpulkan media visual $2 \mathrm{D}$ berupa gambar organ sistem pernafasan manusia, gambar animasi, video, dan materi pembelajaran. Spesifikasi multimedia yang dikembangkan, dapat dilihat pada website dengan alamat http://lilisuryani-mediapembelajaran.000webhostapp.com/. Desain multimedia interktif biologi menggunakan software adobe flash dan materi yang dimuat tentang sistem pernafasan manusia. Fiturnya terdiri atas home, profil, materi, evaluasi, animasi, games, glosarium, dan referensi. Dilengkapi dengan penambahan langkahlangkah petunjuk penggunaan website, audio musik soundcloud pada tampilan halaman muka yang diberi nama Biomics. Video animasi sistem pernafasan yang di tampilkan bersumber dari youtube. Contohcontoh animasi yang ditampilkan dalam bentuk animasi flash dengan format swf. Untuk melakukan 
transfer data dari ke akun web hosting menggunakan layanan https://www.000webhost.com. Dilengkapi fitur live chat, sehingga siswa dapat langsung berkomunikasi secara interaktif. Materi yang diinput pada media animasi berbasis website ialah mekanisme sistem pernafasan pada manusia. Produk yang dihasilkan dapat diakses secara online dan user sepeti guru dan siswa Sekolah Menengah Atas (SMA).

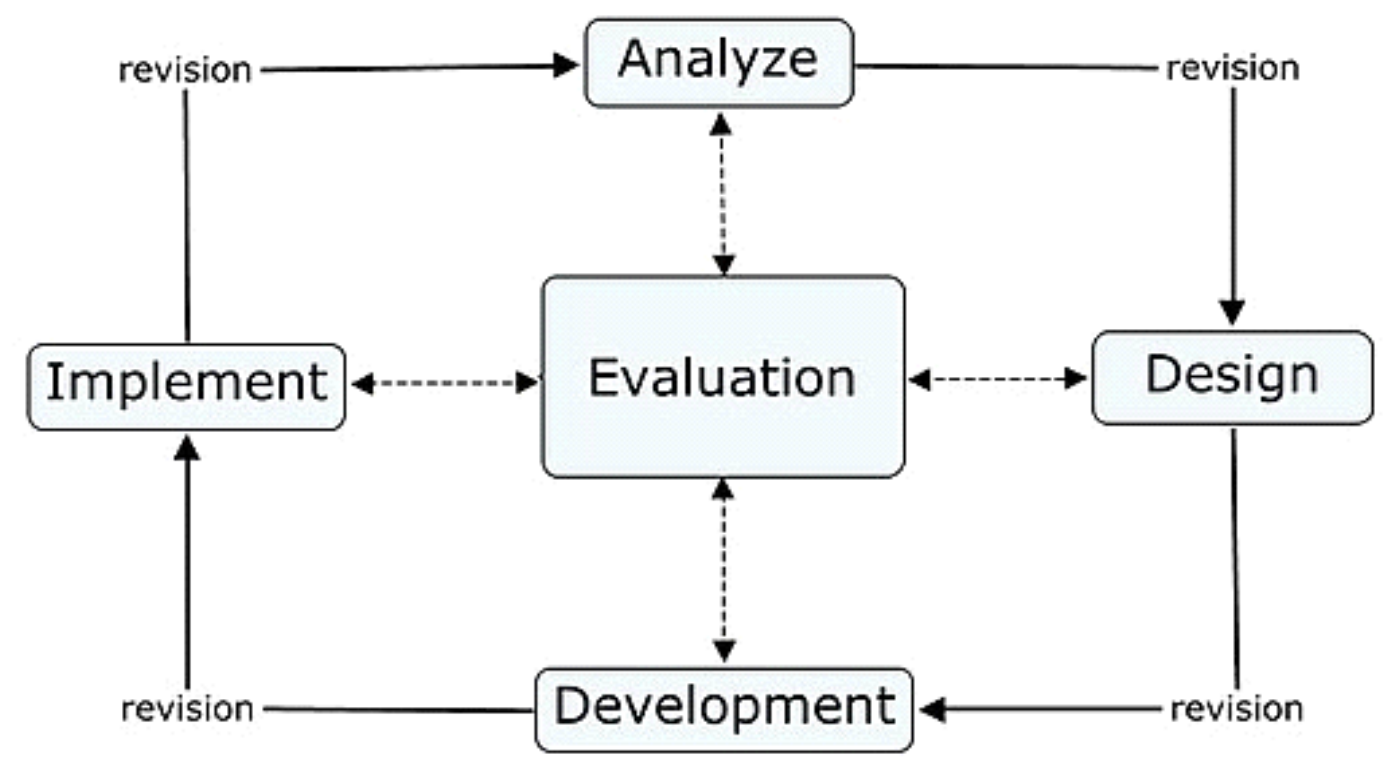

Gambar 1. Model Pengembangan ADDIE (Sumber: Norbert M. Seel, et.al, 2017)

Tahap pengembangan (development) dilakukan pembuatan produk diawali dengan menyiapkan bahan-bahan berupa gambar sistem pernafasan manusia, video, dan gambar animasi, uraian materi, kompetensi dasar serta mencantumkan indikator. Materi yang akan disajikan mengikuti prinsip pembelajaran yang sesuai dengan tujuan pembelajaran. Setelah menyiapkan produk awal yang akan dikembangkan maka tahap selanjutnya ialah dengan membuat produk kemudian memvalidasi produk tersebut oleh validator materi maupun validator media.

Tahap Implementasi (implementation) merupakan tahapan penggunaan produk dalam pembelajaran. Produk yang dihasilkan telah divalidasi oleh tim validator. Selanjutnya, produk diuji coba pada siswa yang tujuannya untuk mengetahui efektivitasnya dalam pembelajaran di dalam kelas. Uji coba produk dilakukan pada kelompok kecil yang terdiri dari 6 orang siswa dan akan di revisi apabila terdapat kekurangan. Lebih lanjut akan dilakukan uji coba produk pada kelompok besar yang terdiri dari 40 orang siswa. Tahap evaluasi (evaluation) dilaksanakan untuk melihat apakah multimedia interaktif biologi berbasis website pada materi sistem pernafasan yang dikembangkan sesuai dengan harapan awal atau tidak. Jika terdapat kekurangan dalam produk yang dikembangkan maka dilakukan perbaikan serta hasil dari perbaikan tersebut akan dilihat kelayakannya secara keseluruhan pada media yang telah dibuat oleh ahli media dan ahli materi. Tahapan evaluasi dasarnya bisa terjadi pada semua tahapan baik analisis, desain, pengembangan, implementasi, dan evaluasi. Dari hasil validasi diketahui ketercapaian tujuan pengembangan produk dan juga sebagai acuan merevisi produk yang dikembangkan agar sesuai dengan kebutuhan pembelajaran.

Instrumen penelitian, yaitu angket yang diberikan kepada validator materi dan validator media untuk mendapatkan penilaian dan komentar. Angket uji produk yang diberikan kepada siswa untuk mendapatkan penilaian dan komentar kemenarikan dari produk pada saat digunakan oleh siswa. Jenis 
data yang diperoleh berupa data kuantitatif dan data kualitatif. Data kuantitatif diperoleh dari hasil validasi oleh ahli validasi materi dan ahli media. Data kualitatif berupa informasi kritik dan saran juga diperoleh dari hasil validasi oleh para validator dan hasil uji coba produk yang dapat digunakan untuk perbaikan produk yang dikembangkan menjadi lebih baik.

Data penelitian dianalisis secara deskriptif, selanjutnya nilai hasil analisis disesuikan dengan kriteria kevalidan dari hasil validasi dan uji coba produk (Rusdi, 2018). Kriteria kevalidan produk yang telah dikembangkan dapat dilihat pada Tabel 1.

Tabel 1. Kriteria Kevalidan

\begin{tabular}{ccl}
\hline Rata-rata Nilai & Kriteria & \multicolumn{1}{c}{ Kesimpulan } \\
\hline $85-100$ & Sangat baik & Produk dapat digunakan tanpa revisi \\
$69-84$ & Baik & Produk dapat digunakan dengan sedikit revisi \\
$53-68$ & Kurang baik & Produk dapat digunakan dengan banyak revisi \\
$37-52$ & Tidak baik & Produk masih perlu konsultasi intensif \\
\hline
\end{tabular}

\section{HASIL PENELITIAN DAN PEMBAHASAN}

Pada tahap analisis didapatkan data bahwa guru dan siswa membutuhkan media yang dapat digunakan dimana saja, kapan saja dan tidak terbatas jumlahnya. Hal tersebut sesuai dengan hasil wawancara yang dilakukan kepada tiga orang guru dan 40 orang siswa di SMA N 4 Kota Jambi. Materi pelajaran yang dianggap sulit adalah materi sistem pernafasan manusia. Mengingat materi ini membutuhkan gambar, video, animasi dan keterangan dalam mempelajarinya sehingga siswa menjadi tertarik dan tidak bosan dalam mempelajarinya. Berdasarkan wawancara bersama guru juga menyebutkan bahwa dalam materi sistem pernafasan untuk menggunakan buku siswa masih ada yang bingung dalam memahami materi. Pada wawancara tersebut guru juga menyampaikan bahwa penggunaan web belajar untuk materi sistem pernafasan manusia belum ada untuk siswa kelas XI MIPA di SMA Negeri 4 Kota Jambi. Apabila materi pembelajaran diintegrasikan dalam bentuk website maka siswa bisa mengaksesnya karena tidak terikat ruang dan waktu.

Tahap desain (design), perancangan multimedia interaktif biologi berbasis website memerlukan waktu sekitar kurang lebih empat bulan meliputi persiapan materi sistem pernafasan, video, gambar, dan animasi dari berbagai sumber baik internet maupun dari buku yang relevan, membuat story board dan mendesain tampilan website. Pada tahapan pembuatan produk memiliki tiga tim kerja yang mempunyai peran masing-masing yang terdiri atas penulis, pembimbing, dan tim ahli. Bagian depan multimedia interaktif biologi berbasis website dapat dilihat pada Gambar 2. Tahap pengembangan (development), dilakukan validasi multimedia interaktif biologi berbasis website kepada ahli media dan ahli materi sebanyak tiga kali. Hal ini dimaksudkan agar mendapatkan penilaian dan saran untuk perbaikan produk yang dikembangkan.

Kritik dari ahli media pada validasi ke pertama, yaitu produk yang dikembangkan tulisannya kurang menarik, tidak teratur dan tidak rapi. Video yang disajikan suaranya kuran jelas dan gambar yang disajikan juga masih kurang menarik. Pada validasi ke dua, validator media memberikan saran dan kritikan bahwa media yang dikembangkan loadingnya lama, warna kurang menarik dan sumber referensi belum dicantumkan. Pada validasi ke tiga, validator media memberikan komentar untuk melakukan uji coba produk. Adapun kritik dari validator materi adalah materi yang disajikan tidak sesuai dengan tingkat materi SMA. Materi yang disajikan ada yang miskonsepsi jadi perlu diperbaiki. Materi yang ditampilkan juga masih kurang lengkap, sehingga perlu diperbaiki untuk perbaikan kualitas. Rangkuman hasil validasi multimedia interaktif biologi berbasis website oleh ahli media dan ahli materi dapat dilihat pada Tabel 2. 
Pada tahap implementasi, produk yang sudah divalidasi oleh para ahli, selanjutnya dilakukan uji coba pada kelompok kecil yang terdiri dari 6 orang siswa. Diperoleh skor sebesar $86 \%$ dengan kategori sangat baik (Tabel 3).

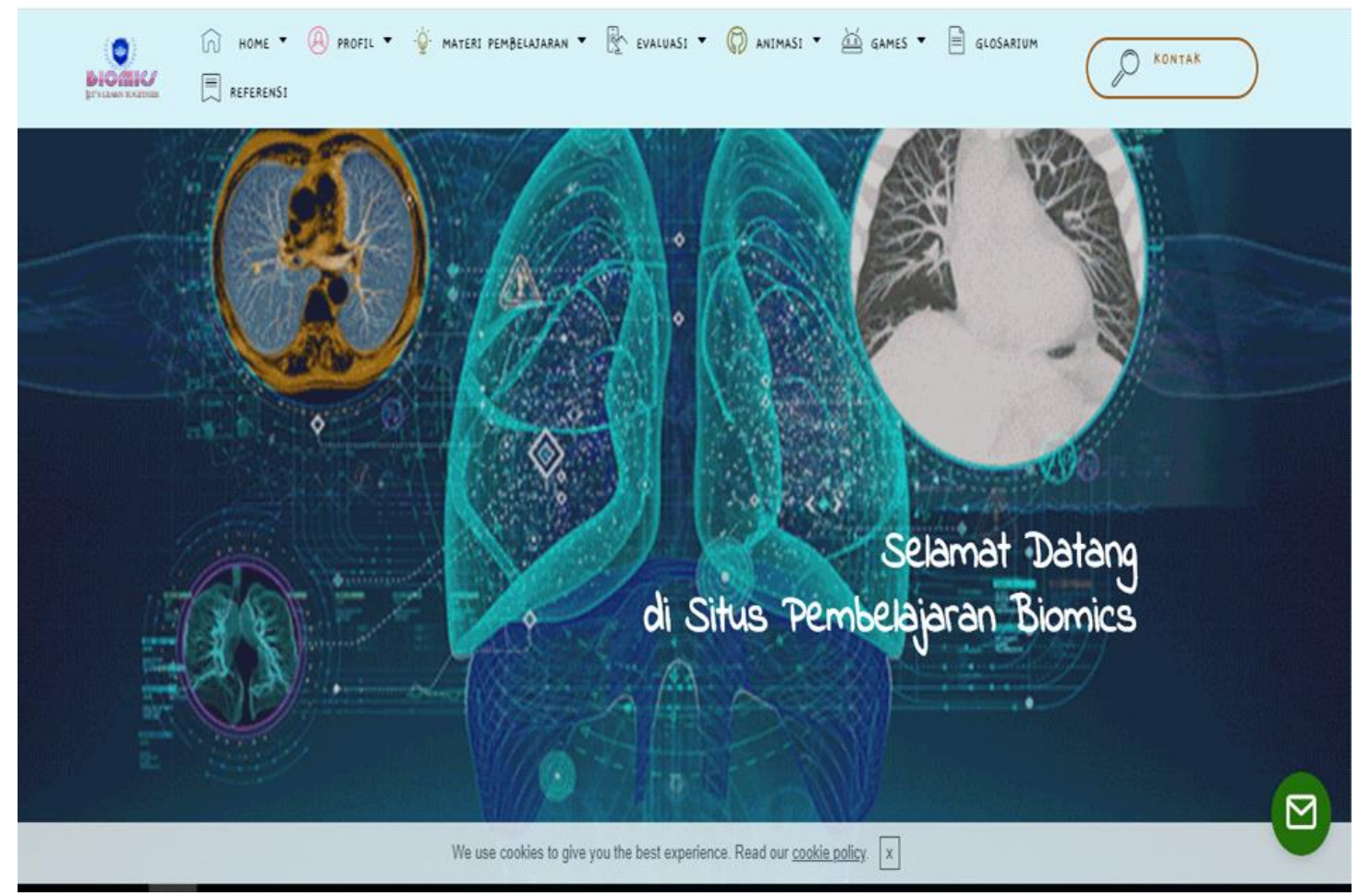

Gambar 2. Bagian Depan Multimedia Interaktif Biologi Berbasis Website (Sumber: Dokumentasi Pribadi, 2019)

Tabel 2. Rangkuman Hasil Validasi Multimedia Interaktif Biologi Berbasis Website

\begin{tabular}{ccc}
\hline Validator & Skor & Persentase (\%) \\
\hline Ahli media & 72 & 90 \\
Ahli materi & 49 & 87,5 \\
\hline
\end{tabular}

Tabel 3. Hasil Uji Coba Produk Pada Kelompok Kecil

\begin{tabular}{|c|c|c|c|c|c|}
\hline Variabel & Indikator & Deskripsi & $\begin{array}{l}\text { Jumlah } \\
\text { Respon }\end{array}$ & $\begin{array}{l}\text { Persentase } \\
(\%)\end{array}$ & Kategori \\
\hline \multirow[t]{8}{*}{$\begin{array}{l}\text { Multimedia } \\
\text { Interaktif biologi } \\
\text { berbasis website }\end{array}$} & \multirow[t]{3}{*}{$\begin{array}{l}\text { Tampilan } \\
\text { Produk }\end{array}$} & $\begin{array}{l}\text { Tampilan awal situs website tidak } \\
\text { menoton sehingga tidak } \\
\text { menimbulkan kebosanan }\end{array}$ & 19 & $79,2 \%$ & Baik \\
\hline & & $\begin{array}{l}\text { Pemakaian warna terhadap } \\
\text { tampilan multimedia website yang } \\
\text { menarik }\end{array}$ & 18 & $75 \%$ & Baik \\
\hline & & $\begin{array}{l}\text { Desain website tidak ketinggalan } \\
\text { zaman dan update }\end{array}$ & 19 & $79,2 \%$ & Baik \\
\hline & \multirow{5}{*}{$\begin{array}{l}\text { Kesesuaian } \\
\text { produk dengan } \\
\text { materi } \\
\text { pembelajaran } \\
\text { Kemenarikan } \\
\text { produk } \\
\text { Manfaat } \\
\text { produk }\end{array}$} & $\begin{array}{l}\text { Kesesuaian produk dengan materi } \\
\text { pembelajaran }\end{array}$ & 23 & $95,8 \%$ & $\begin{array}{l}\text { Sangat } \\
\text { Baik }\end{array}$ \\
\hline & & $\begin{array}{l}\text { Ketersediaan bantuan berupa } \\
\text { Livechat }\end{array}$ & 21 & $81,5 \%$ & $\begin{array}{l}\text { Sangat } \\
\text { Baik }\end{array}$ \\
\hline & & $\begin{array}{l}\text { Tampilan web dapat menarik } \\
\text { pengguna untuk mengunj unginya }\end{array}$ & 23 & $95,8 \%$ & $\begin{array}{l}\text { Sangat } \\
\text { Baik }\end{array}$ \\
\hline & & $\begin{array}{l}\text { Dapat membangkitkan minat dalam } \\
\text { menjalankan program }\end{array}$ & 21 & $87,5 \%$ & $\begin{array}{l}\text { Sangat } \\
\text { Baik }\end{array}$ \\
\hline & & $\begin{array}{l}\text { Pengguna dapat mengoperasikan } \\
\text { program secara mandiri }\end{array}$ & 20 & $83,3 \%$ & $\begin{array}{l}\text { Sangat } \\
\text { Baik }\end{array}$ \\
\hline
\end{tabular}




\begin{tabular}{lccc}
$\begin{array}{l}\text { Pengguna tidak merasa bosan } \\
\text { menggunakan program }\end{array}$ & 23 & $95,8 \%$ & SangatBaik \\
$\begin{array}{l}\text { Program bebas dari kesalahan } \\
\text { yang mengakibatkan berhentinya }\end{array}$ & 21 & $87,5 \%$ & SangatBaik \\
$\begin{array}{l}\text { program } \\
\text { Rata-rata }\end{array}$ & & $86 \%$ & Sangat baik \\
\hline
\end{tabular}

Respon siswa pada uji coba kelompok kecil menunjukkan respon positif, namun mereka masih mengeluhkan tentang loading yang masih lambat. Setelah dilakukan revisi berdasarkan uji coba kelompok kecil, selanjutnya dilakukan uji coba kelompok besar kepada 40 orang siswa yaitu diperoleh skor sebesar 88\% dengan kategori sangat baik (Tabel 4) dan mendapatkan respon positif dari siswa.

Tabel 4. Hasil Uji Coba Produk Pada Kelompok Besar

\begin{tabular}{|c|c|c|c|c|c|}
\hline Variabel & Indikator & Deskripsi & $\begin{array}{l}\text { Jumlah } \\
\text { Respon }\end{array}$ & $\begin{array}{l}\text { Persentase } \\
(\%)\end{array}$ & Kategori \\
\hline $\begin{array}{l}\text { Multimedia } \\
\text { Interaktif biolog } \\
\text { berbasis }\end{array}$ & Tampilanproduk & $\begin{array}{l}\text { Tampilan awal situs website tidak } \\
\text { menoton sehingga tidak menimbulkan } \\
\text { kebosanan }\end{array}$ & 146 & $89,4 \%$ & Baik \\
\hline \multirow[t]{9}{*}{ website } & & $\begin{array}{l}\text { Pemakaian warna terhadap tampilan } \\
\text { multimedia website yang menarik }\end{array}$ & 136 & $85 \%$ & Baik \\
\hline & & $\begin{array}{l}\text { Desain website tidak ketinggalan } \\
\text { zaman dan update }\end{array}$ & 132 & $82,5 \%$ & Baik \\
\hline & $\begin{array}{l}\text { Kesesuaian produk } \\
\text { dengan materi } \\
\text { pembelajaran }\end{array}$ & $\begin{array}{l}\text { Kesesuaian produk dengan materi } \\
\text { pembelajaran }\end{array}$ & 138 & $86,25 \%$ & $\begin{array}{l}\text { Sangat Baik } \\
\text { Baik }\end{array}$ \\
\hline & Kemenarikanproduk & Ketersediaan bantuan berupa livechat & 149 & $93,12 \%$ & Sangat Baik \\
\hline & Manfaat produk & $\begin{array}{l}\text { Tampilan web dapat menarik } \\
\text { pengguna untuk mengunjunginya }\end{array}$ & 148 & $92,5 \%$ & Sangat Baik \\
\hline & & $\begin{array}{l}\text { Dapat membangkitkan minat dalam } \\
\text { menjalankan program }\end{array}$ & 136 & $85 \%$ & Sangat Baik \\
\hline & $\begin{array}{l}\text { Kemudahanpenggun } \\
\text { aanproduk }\end{array}$ & $\begin{array}{l}\text { Pengguna tidak merasa bosan } \\
\text { menggunakan program }\end{array}$ & 142 & $\begin{array}{l}88,75 \\
\%\end{array}$ & Sangat Baik \\
\hline & & $\begin{array}{l}\text { Pengguna tidak merasa bosan } \\
\text { menggunakan program }\end{array}$ & 142 & $\begin{array}{l}88,75 \\
\%\end{array}$ & Sangat Baik \\
\hline & & $\begin{array}{l}\text { Program bebas dari kesalahan yang } \\
\text { mengakibatkan berhentinya program } \\
\text { Rata-rata }\end{array}$ & 144 & $\begin{array}{c}90 \% \\
88,00 \%\end{array}$ & $\begin{array}{l}\text { Sangat Baik } \\
\text { Baik } \\
\text { Sangat Baik }\end{array}$ \\
\hline
\end{tabular}

Tahap evaluasi, produk yang dikembangkan telah melalui proses evaluasi yang panjang mulai dari validator media, validator materi, uji coba kelompok kecil dan uji coba kelompok besar. Adapun saran dan kritik pada produk penelitian ini, yaitu produk yang dikembangkan tulisannya kurang menarik, tidak teratur dan tidak rapi. Video yang disajikan suaranya kurang jelas dan gambar yang disajikan juga masih kurang menarik. Loading media yang dikembangkan masih lama. Warna kurang menarik dan sumber referensi belum dicantumkan. Materi yang disajikan tidak sesuai dengan tingkat materi SMA. Materi yang disajikan ada yang miskonsepsi jadi perlu diperbaiki. Tampilan animasi sistem pernapasan pada manusia dapat dilihat pada Gambar 3. Tampilan multimedia interaktif biologi berbasis website dapat dilihat pada Gambar 4.

Multimedia interaktif biologi berbasis website pada materi sistem pernafasan setelah dilakukan uji coba kelayakan, yaitu dinyatakan layak untuk digunakan sebagai media pembelajaran di sekolah maupun mandiri oleh siswa. Hal ini sesuai dengan butir penilaian skor 4 tertinggi pada hasil uji coba kelompok kecil yakni sebesar $95,8 \%$ pada indikator kesesuaian produk dengan materi pembelajaran, tampilan web dapat menarik pengguna untuk mengunjunginya, dan pengguna tidak merasa bosan menggunakan 
program. Menurut Supardi (2014), bahwa dengan menggunakan multimedia pembelajaran interaktif dapat mempengaruhi minat belajar siswa.

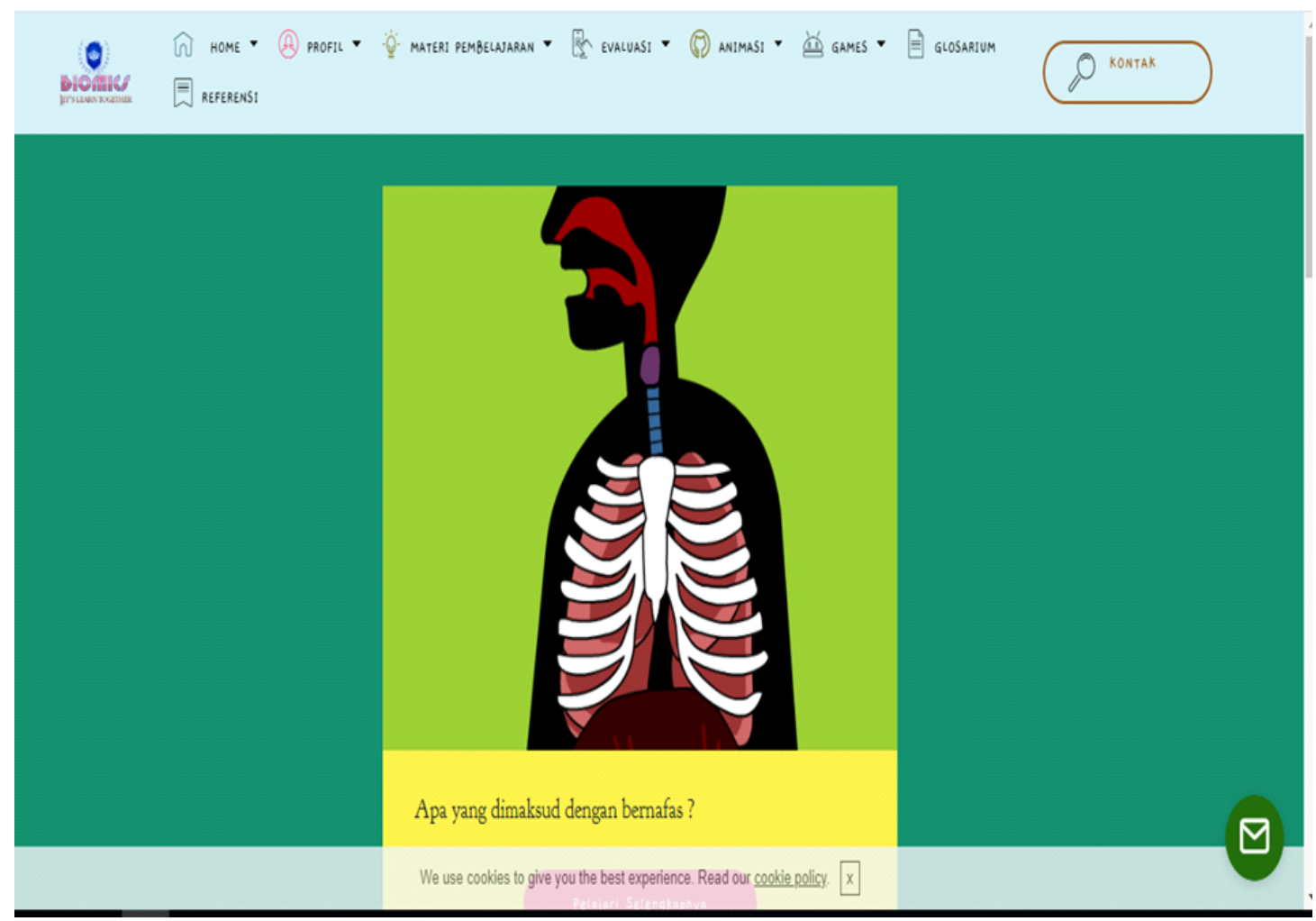

Gambar 3. Tampilan Animasi Sistem Pernapasan Pada Manusia (Sumber: Dokumentasi Pribadi, 2019)
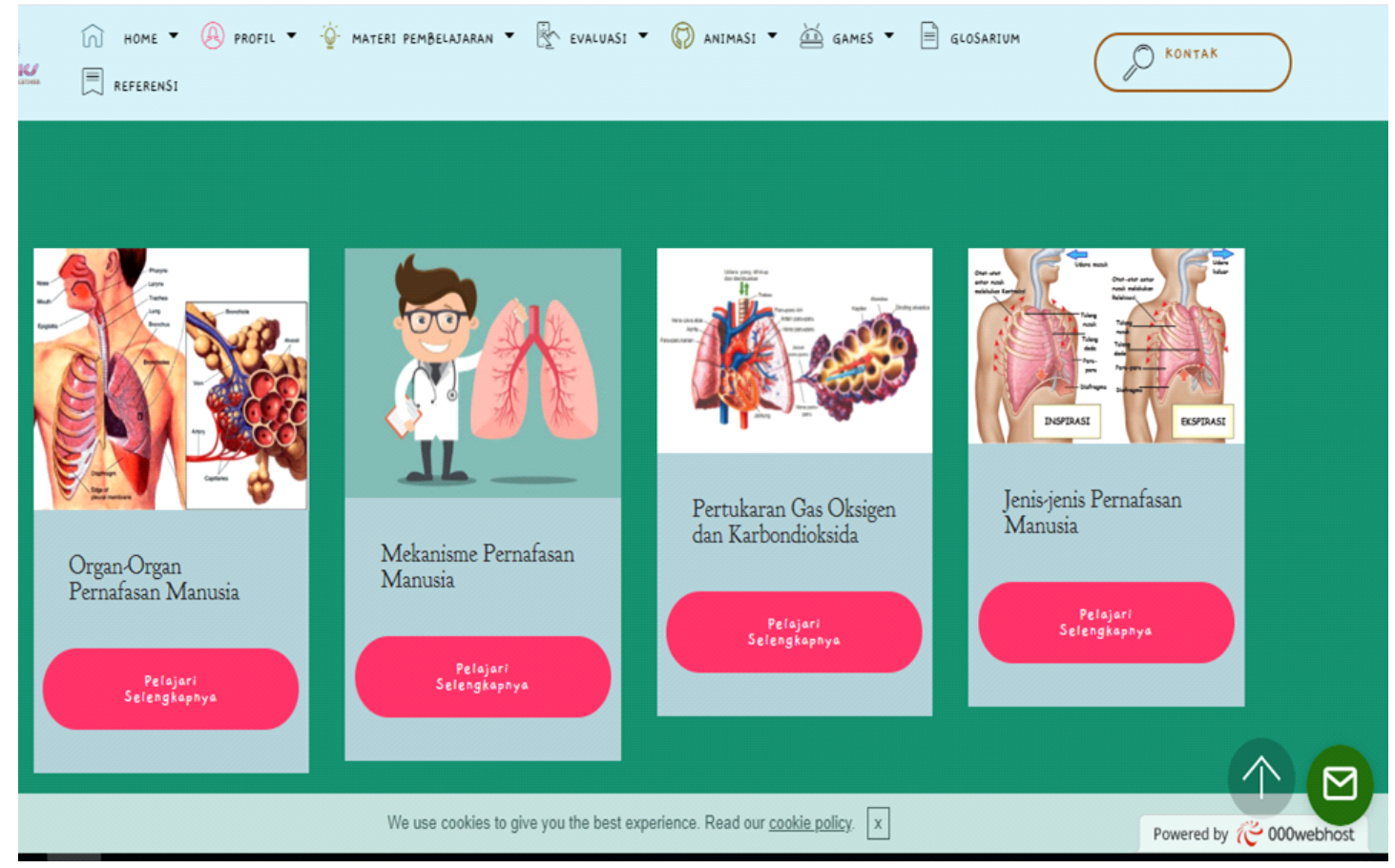

Gambar 4. Tampilan Multimedia Interaktif Biologi Berbasis Website (Sumber: Dokumentasi Pribadi, 2019)

Pemanfaatan multimedia interaktif biologi ini, memberikan kemudahan pada siswa dalam mengakses yaitu dengan menggunakan smartphone yang mereka miliki. Hal ini sesuai dengan pendapat 
Muhaimin dkk (2019) bahwa Information and Communication of Technology (ICT) mempermudah akses dalam memperoleh informasi pelajaran. Interaktif yang diharapkan mampu memberikan keleluasaan kepada siswa untuk menentukan ketertarikannya terhadap pembelajaran yang akan dilaksanakannya. Kemudian ditambahkan oleh Purnama, Hubeis, \& Matindas (2009) menyatakan bahwa kemudahan aplikasi berpengaruh positif terhadap frekuensi akses media, artinya semakin tinggi tingkat kemudahan aplikasi, maka cenderung berpengaruh terhadap semakin tingginya frekuensi akses media. Hai ini dapat dipahami bahwa semakin rumit aplikasi yang tersedia pada website akan mempengaruhi terhadap rendahnya frekuensi akses media.

Demikian pula pada hasil tanggapan ujicoba kelompok besar terhadap pernyataan dengan persentase sangat tinggi terlihat pada ketersediaan bantuan berupa live chat sebesar $93,12 \%$. Pada indikator program bebas dari kesalahan yang mengakibatkan berhentinya program mendapatkan skor 4 dengan persentase sebesar $90 \%$ dan pada tampilan web dapat menarik pengguna untuk mengunjunginya sebesar $92,5 \%$. Maka hasil keseluruhan tanggapan ujicoba kelompok besar yang tertinggi tersebut dapat disimpulkan bahwa siswa lebih mengutamakan ketersediaan bantuan berupa fitur chat hal ini dikarenakan fitur chat dalam multimedia interaktif biologi berbasis website dapat memberikan kemudahan dalam berkomunikasi. Multimedia interaktif dapat meningkatkan motivasi siswa (Triyanti, 2015). Menurut Istiqomah (2016), terdapat keuntungan menggunakan e-chat yakni dapat bertukar pesan atau melakukan komunikasi baik teks, suara, maupun video.

Kelebihan menggunakan multimedia pembelajaran yang diintegritasikan dalam bentuk website (Putranto, 2011). Ada beberapa faktor yang menguntungkan dari pembelajaran menggunakan internet ialah dari segi biaya yang murah, fleksibel waktu, fleksibel tempat, fleksibel kecepatan pembelajaran, dan efektifitas terhadap pengajaran. Hal yang sama juga dikemukakan oleh Puji, Gulo, \& Ibrahim, (2014) menyatakan bahwa salah satu pemanfaatan teknologi pembelajaran seperti multimedia interaktif ialah materi pelajaran akan terasa nyata karena tersaji dengan kasat mata, dapat merangsang berbagai indera untuk berinteraksi, visualisasi dengan bentuk teks, gambar audio, video dan animasi akan lebih mudah diingat dan ditangkap oleh siswa. Media pembelajaran dapat meningkatkan antusias belajar dan hasil belajar siswa (Mulyani, 2019). Multimedia dapat meningkatkan motivasi dan hasil belajar siswa, dapat diakses dimana saja, kapan saja dan memudahkan siswa untuk belajar biologi. Siswa mendapat alternatif sumber belajar dan mengisi waktu dengan positif. Hal ini didukung dengan hasil penelitian ini bahwa multimedia interaktif biologi berbasis website dan animasi mendapat respon positif dari guru dan siswa.

\section{SIMPULAN}

Multimedia interaktif biologi berbasis website yang telah dikembangkan dinyatakan valid dan layak untuk digunakan dalam pembelajaran biologi. Hal ini terbukti dari hasil validasi dinyatakan valid pada aspek media (90\% kriteria sangat baik), aspek materi (87,5\% kriteria sangat baik), dan aspek kemenarikan ( $88 \%$ kriteria sangat baik).

\section{RUJUKAN}

Anggraeni, R. D., Sulton, S., \& Sulthoni, S. (2019). Pengaruh Multimedia Tutorial Terhadap Hasil Belajar Bahasa Indonesia. Jurnal Kajian Teknologi Pendidikan, 2(2), 96-101. http://dx.doi.org/10.17977/ um038v2i22019p096

Aprilia, S. N., Wijaya, A. F., \& Suryadi, S. (2014). Efektivitas Website Sebagai Media E-Government Dalam Meningkatkan Pelayanan Elektronik Pemerintah Daerah (Studi Pada Website Pemerintah Daerah Kabupaten Jombang). Wacana (Jurnal Sosial Dan Humaniora), 17(2), 126-135. Retrieved 
from https://www.neliti.com/publications/40110/efektivitas-website-sebagai-media-e-governmentdalam-meningkatkan-pelayanan-elek

Arsyad, A. (2013). Media Pembelajaran; Edisi Revisi. Retrieved from http://r2kn.litbang.kemkes.go.id: 8080/handle/123456789/63939

Faryanti, H., \& Panjaitan, R. G. P. (2016). Respon Siswa Terhadap Film Animasi Zat Aditif. Jurnal Pendidikan dan Pembelajaran, 5(3). Retrieved from http://jurnal.untan.ac.id/index.php/jpdpb/article/ view/14225

Ferry, D., \& Kamil, D. (2019). Peningkatan Hasil Belajar Biologi Siswa Melalui Penerapan Media Video Animasi Tiga Dimensi (3D). Pedagogi Hayati, 3(2), 1-11. https://doi.org/https://doi.org/10.31629/ ph.v3i2.1641

Istigfar, A. M., Wijaya, M., \& Nurmila, N. (2018). Pengaruh Multimedia Ncesoft Flipbook Maker Pada Materi Pembelajaran Pengendalian Gulma Terhadap Motivasi Dan Hasil Belajar Siswa Kelas XI ATPH SMK Negeri 1 Bone-Bone. Jurnal Pendidikan Teknologi Pertanian, 4, 66-78. https://doi.org/ 10.26858/jptp.v1i0.6234

Istiqomah, L. N. L. (2016). Penerapan Analisis Konjoin Terhadap Preferensi Penggunaan Instant Messenger. Retrieved from https://repository.ipb.ac.id/handle/123456789/80912

Januarisman, E., \& Ghufron, A. (2016). Pengembangan Media Pembelajaran Berbasis Web Mata Pelajaran IImu Pengetahuan Alam Untuk Siswa Kelas VII. Jurnal Inovasi Teknologi Pendidikan, 3(2), 166-182. https://doi.org/10.21831/jitp.v3i2.8019

Kurniawan, A., \& Masjudin. (2017). Pengembangan Buku Ajar Microteaching Berbasis Praktik Untuk Meningkatkan Keterampilan Mengajar Calon Guru. Prosiding Seminar Nasional Pendidik Dan Pengembang Pendidikan Indonesia Dengan Tema "Membangun Generasi Berkarakter Melalui Pembelajaran Inovatif, 9-16. Retrieved from http://ejournal.mandalanursa.org/index.php/Semnas/ article/view/166

Muhaimin, M., Habibi, A., Mukminin, A., Saudagar, F., Pratama, R., Wahyuni, S., Indrayana, B. (2019). A Sequential Explanatory Investigation of TPACK: Indonesian Science Teachers' Survey and Perspective. Journal of Technology and Science Education, 9(3), 269-281. https://doi.org/ 10.3926/jotse.662

Mukminin, A., Habibi, A., Muhaimin, A., Haryanto, E., \& Setiono, P. (2019). Vocational Technical High School Teachers' Beliefs Towards ICT For The 21st Century Education: Indonesian Context. Problems of Education in the $21^{\text {st }}$ century, $77(1), 22-38$. Retrieved from https://scientiasocialis.It/ pec/biblio?f[author] $=1539$

Mulyani, S. W. W. (2019). Peningkatan Hasil Belajar Siswa Materi Limbah Lunak Melalui Media Pembelajaran Carta. Edubiotik: Jurnal Pendidikan, Biologi dan Terapan, 4(01), 45-52. https://doi.org/10.33503/ebio.v4i01.440

Murdiyani, I. (2012). Pembelajaran Biologi Menggunakan Metode E-Learning Berbasis Multiple Intelligences Pada Materi Sistem Gerak Manusia. Innovative Journal of Curriculum and Educational Technology, 1(1). Retrieved from https://journal.unnes.ac.id/sju/index.php/ujet/article/view/130

Prasojo, L. D., Habibi, A., \& Mukminin, A. (2017). Managing Digital Learning Environments: Student Teachers' Perception on the Social Networking Services Use in Writing Courses in Teacher Education. Turkish Online Journal of Educational Technology-TOJET, 16(4), 42-55. Retrieved from https://eric.ed.gov/?id=EJ1160635

Prasojo, L. D., Mukminin, A., Habibi, A., Marzulina, L., Muhammad, S., \& Harto, K. (2018). Learning to Teach in A Digital Age: ICT Integration and EFL Student Teachers'teaching Practices. Teaching English with Technology, 18(3), 18-32. Retrieved from https://www.ceeol.com/search/articledetail?id=683373

Prawiradilaga, D. S. (2016). Mozaik teknologi pendidikan: E-learning. Kencana. Retrieved from https://books.google.co.id/books?hl=en\&lr=\&id=SdxDDwAAQBAJ\&oi 
Puji, K. M., Gulo, F., \& Ibrahim, A. R. (2014). Pengembangan Multimedia Interaktif Untuk Pembelajaran Bentuk Molekul di SMA. Jurnal Penelitian Pendidikan Kimia: Kajian Hasil Penelitian Pendidikan Kimia, 1(1), 59-65. https://doi.org/10.36706/jppk.v1i1.2385

Purnama, D. H., Hubeis, M., \& Matindas, K. (2009). Efektivitas Komunikasi Pembelajaran Melalui Media Website Untuk Materi Ajaran Fisika (Kasus Siswa Kelas 3 SMAN 1 Jakarta Pusat). Jurnal Komunikasi Pembangunan, 7(1). https://doi.org/10.29244/jurnalkmp.7.1.\%25p

Putranto, A. (2011). Perancangan Sistem E-Learning Berbasis Web dengan Analisis SWOT Pada Sekolah Menengah Umum. ComTech: Computer, Mathematics and Engineering Applications, 2(2), 646-661. https://doi.org/10.21512/comtech.v2i2.2814

Putu, F. Y., I Ketut, A., \& I Nyoman Gede, S. (2014). Efektifitas Penggunaan Media Cetak Dan Media Elektronika Dalam Promosi Kesehatan Terhadap Peningkatan Pengetahuan Dan Perubahan Sikap Siswa SD. JKL (Jurnal Kesehatan Lingkungan), 4(1), 29-39. Retrieved from http://repository. poltekkes-denpasar.ac.id/1905/

Riyanto, R., \& Susilawati, L. (2019). Penerapan Media Aurora Animasi 3D Maker Untuk Meningkatkan Hasil Belajar Kognitif Mahasiswa Biologi Ikip Budi Utomo Malang. Edubiotik : Jurnal Pendidikan, Biologi dan Terapan, 4(01), 52-57. https://doi.org/10.33503/ebio.v4i01.438

Rusdi, M. (2018). Penelitian Desain Dan Pengembangan Kependidikan: Konsep, Prosedur, Dan Sintesis Pengetahuan Baru. In Depok: RajaGrafindo Persada. Retrieved from http://www.rajagrafindo. co.id/produk/penelitian-desain-dan-pengembangan-kependidikan-rusdi/

Sadikin, A., \& Hakim, N. (2019). Pengembangan Media E-Learning Interaktif Dalam Menyongsong Revolusi Industri 4. Jurnal IImiah Pendidikan Biologi, 5(2), 131-138. https://doi.org/10.22437/ bio.v5i2.7590

Seel, M. N., Lehmann, T., Blumschein, P., \& Podolskiy, O. A. (2017). Instructional Design for Learning. Journal of Chemical Information and Modeling (Vol. 53). https://doi.org/10.1017/CBO9781 107415324.004

Sukiyasa, K., \& Sukoco, S. (2013). Pengaruh media animasi terhadap hasil belajar dan motivasi belajar siswa materi sistem kelistrikan otomotif. Jurnal Pendidikan Vokasi, 3(1). https://doi.org/10.21 831/jpv.v3i1.1588

Supardi, A. (2014). Penggunaan Multimedia Interaktif Sebagai Bahan Ajar Suplemen Dalam Peningkatan Minat Belajar. Jurnal IImiah Pendidikan Dasar, 1(2), 161-167. http://dx.doi.org/10.30659/pendas. 1.2.161=167

Suprihatin, S. (2017). Penggunaan Media Pengajaran Untuk Meningkatkan Prestasi Belajar Mata Pelajaran PPKn Pada Siswa Kelas X Semester I Smk Negeri 1 Bendo Kecamatan Bendo Kabupaten Magetan Tahun Ajaran 2014/2015. Jurnal Pancasila Dan Kewarganegaraan, 3(2), 320 333. http://doi.org/10.25273/citizenship.v3i2.1259

Wilsa, A. W. (2019). Perbedaan Hasil Belajar Siswa Yang Menggunakan Multimedia Interaktif Dengan Buku Teks Dalam Pembelajaran Biologi di SMA. Jurnal Mangifera Edu, 4(1), 62-70. https://doi.org/ 10.31943/mangiferaedu.v4i1.42 